\title{
O GÊNERO INDIGOFERA L. (LEGUMINOSAE-PAPILIONOIDEAE- -INDIGOFEREAE) NO RIO GRANDE DO SUL - BRASIL
}

\author{
Sônia Maria Eisinger ${ }^{1}$
}

Recebido em 13.09.86. Aceito em 23.04.87.

RESUMO - Um levantamento das espécies do gênero Indigofera L. no Estado do Rio Grande do Sul confirmou a ocorrência de quatro espécies: Indigofera sabulicola Benth., I. asperifolia Bong., I. suffruticosa Mill. e I. campestris Bong. É delineado um breve histórico da posição sistemática do gênero. São apresentadas chave para a identificação das espécies estudadas, descrições, ilustraçōes, ocorrência no Estado, bem como dados de habitat, distribuição, floração e frutificação.

Palavras-chave: Indigofera, Leguminosae, Papilionoideae, Sistemática.

ABSTRACT - (Genus Indigofera L. (Leguminosae-Papilionoideae-Indigofereae) in the Rio Grande do Sul - Brazil.) A recent survey of the species of Indigofera L. occuring in the Rio Grande do Sul State, Brazil, revealed four species in the area: Indigofera sabulicola Benth., I. asperifolia Bong., I. suffruticosa Mill. and I. campestris Bong. It is given a short historical review on the systematic position of the genus. Identification key to the species studied, descriptions, illustrations, and data such as distribution, habitat, flowering and frutification are also presented.

Key words: Indigofera, Leguminosae, Papilionoideae, Systematics.

\section{Introdução}

No Brasil, o único representante da tribo Indigofereae Benth., sensu POLHILL (1981), é o gênero Indigofera L. O presente trabalho objetiva o estudo taxonômico de suas espécies no Estado do Rio Grande do Sul, contribuindo desta forma para o melhor conhecimento do gênero e da flora da região.

$O$ gênero foi mencionado pela primeira vez por Linnaeus em 1737 e em 1753 foi incluído pelo mesmo autor em Species Plantarum (LINNAEUS, 1959). Atualmente, segundo POLHILL (1981) ele é constituído de aproximadamente $700 \mathrm{spp}$, distribuídas nas regiões tropicais e subtropicais e suas espécies adaptam-se melhor a áreas semi-áridas. Espécies nativas ocorrem ao longo de estradas, em campos graminosos, matagais e locais abandonados (ALLEN \& ALLEN, 1981).

\footnotetext{
${ }^{1}$ Departamento de Biologia - C.C.N.E. - Universidade Federal de Santa Maria. 97.119. Santa Maria, RS.
} 
BENTHAM (1959), em sua contribuição para a Flora Brasiliensis, descreveu a tribo Indigofereae com 11 espécies de Indigofera para o Brasil e países adjacentes, das quais três com ocorrência também no Estado do Rio Grande do Sul. Mais tarde, colocou o gênero na tribo Galegeae, subtribo Indigofereae (BENTHAM, 1865).

TAUBERT (1894) considerou os subgêneros de Bentham secções de Indigofera. Na secção Euindigofera agrupou as espécies em 6 séries e 8 subséries. Fez também a correção nomenclatural: tribo Galegeae subtribo Indigoferinae. Tal classificação foi seguida por ENGLER \& GILG (1924), BURKART (1942, 1943, 1952) e ALLEN \& ALLEN (1981).

SCHULZE-MENZ (1964) colocou o gênero na tribo Astragaleae, subtribo Indigoferinae.

RYDBERG (1923) adotou tribo Indigofereae na sua monografia para a flora norte-americana. HUTCHINSON (1964) também seguiu esta classificação. POLHILL (1981) aceitou o status tribal de Indigofereae e incluiu nesta, além de Indigofera, Cyamopsis DC., Rhynchotropis Harms e Phylloxylon Baill. Considerou Indigofera um dos mais amplos e distintos gêneros dentro das Papilionoideae tropicais.

Em trabalhos mais restritos referentes à flora da região em estudo, a primeira citação do gênero para o Rio Grande do Sul é de LINDMAN (1898) com Indigofera asperifolia, para as proximidades de Rio Grande. Sucederam-se vários registros da ocorrência do gênero e entre eles citam-se MALME (1931), BORNMUELLER (1834), LUIS (1960) e SCHULTZ \& PORTO (1971).

RAMBO (1953) fez um estudo das leguminosas rio-grandenses e concluiu que Indigofera pertence ao grupo pantropical do contingente brasileiro, que inclui a maior parte das leguminosas do Estado. As espécies em estudo são típicas de formações campestres que podem variar desde estepe até formações arbustivas, secas ou paludosas. I. campestris e $I$. asperifolia têm seu centro de difusão no oeste médio do Brasil, Paraguai e norte da Argentina. I. sabulicola e I. suffruticosa têm seu centro de difusão no Brasil Central ou região equatorial e o Uruguai e nordeste da Argentina como limite sul. Em 1966, Rambo incluiu estas espécies na relação das leguminosas do Herbário Anchieta (PACA).

BARRETO \& KAPPEL (1964) mencionaram I. asperifolia e I. sabulicola, dando enfoque no valor forrageiro destas espécies.

As leguminosas perfazem uma parte considerável das Fanerógamas do Estado e poucos são os trabalhos específicos neste grupo com a finalidade de inventariar as nossas espécies. Este estudo pretende ser uma contribuição neste sentido.

\section{Material e métodos}

Foram feitas viagens de coleta para diversas regiōes fisiográficas do Estado (Figura 1), com o objetivo de levantar os diferentes taxa em estudo, conhecer o seu habitat e a sua ocorrência. O material coletado foi herborizado e incorporado ao Herbário do Departamento de Botânica da Universidade Federal do Rio Grande do Sul (ICN). 


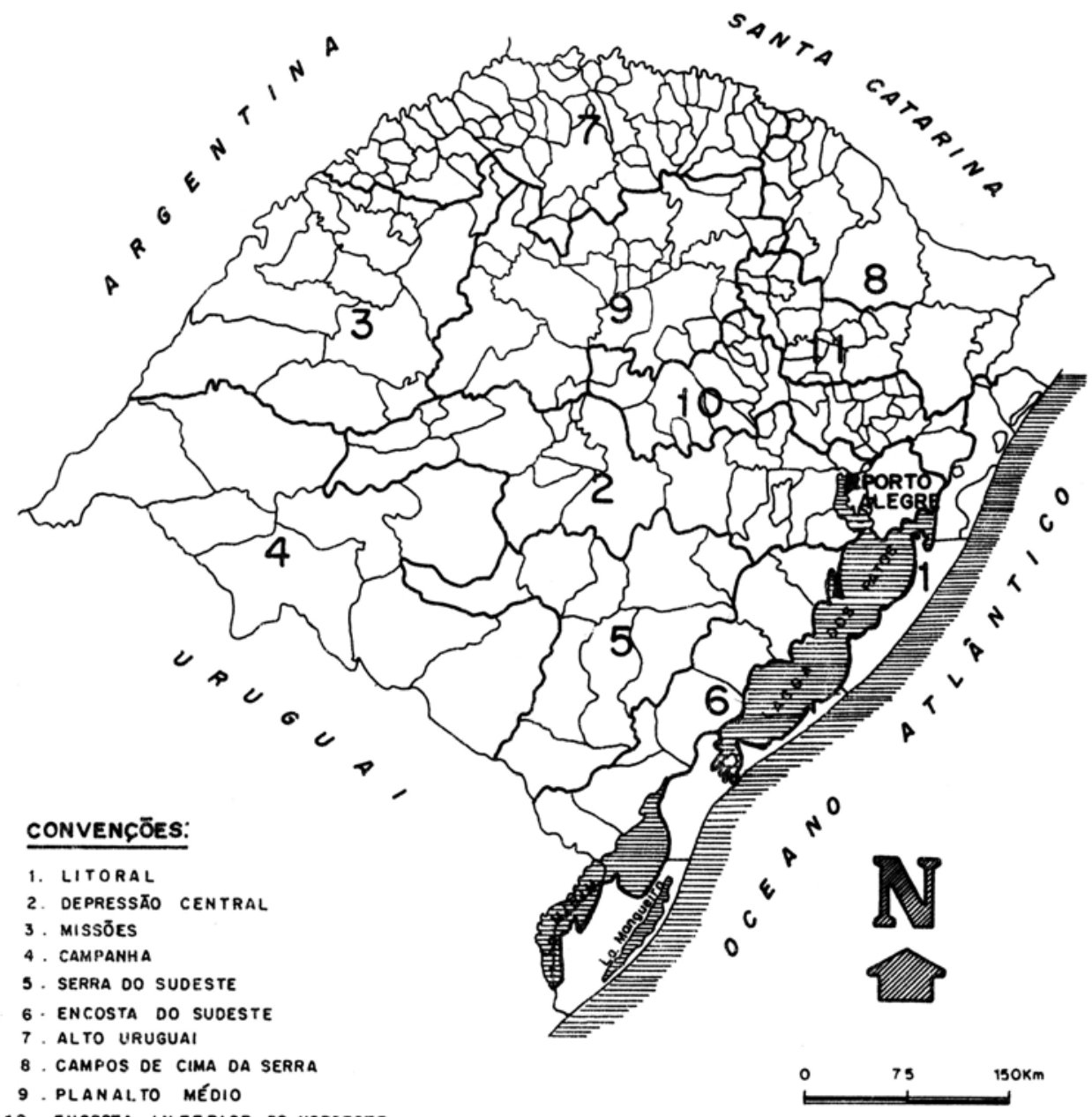

10. ENCOSTA INFERIOR DO NORDESTE

11 . ENCOSTA SUPERIOR DO NOROESTE

ESCALA GRÁFICA Arte Finol: Asses. Teic. Arthur H. Cunho
1987

1. Regiōes Fisiográficas do Estado do Rio Grande do Sul.

Com a finalidade de verificar a amplitude de variação morfológica, a distribuição, dados ecológicos e comparar o material determinado por diversos especialistas, foram revisados os seguintes herbários:

BLA - Herbário do Instituto de Pesquisas Zootécnicas Francisco Osório, do Departamento de Pesquisa da Secretaria da Agricultura do Estado do Rio Grande do Sul, Porto Alegre, RS, Brasil; 
CEN - Herbário do Centro Nacional de Recursos Genéticos - CENARGEM/ EMBRAPA, Brasília, DF, Brasil;

CTES - Herbário da Universidad Nacional del Nordeste, Corrientes, Província de Corrientes, Argentina;

HAS - Herbário Alarich R.H. Schultz da Fundação Zoobotânica do Rio Grande do Sul, Porto Alegre, RS, Brasil;

ICN - Herbário do Departamento de Botânica do Instituto de Biociências da Universidade Federal do Rio Grande do Sul, Porto Alegre, RS, Brasil;

IPRN - Herbário do Instituto de Pesquisas de Recursos Naturais Renováveis da Secretaria da Agricultura do Estado do Rio Grande do Sul, Porto Alegre, RS, Brasil;

LP - Herbário del Museo de La Plata, La Plata, Província de Buenos Aires, Argentina;

MBM - Herbário do Museu Botânico Municipal de Curitiba, PR, Brasil;

PACA - Herbário Anchieta, da Universidade do Vale do Rio dos Sinos, São Leopoldo, RS, Brasil;

PEL - Herbário da Unidade de Execução de Pesquisa Agrícola e Experimentação - EMBRAPA - Pelotas, RS, Brasil;

R - Herbário do Museu Nacional, Rio de Janeiro, RJ, Brasil;

RB - Herbário do Jardim Botânico do Rio de Janeiro, Rio de Janeiro, RJ, Brasil;

SI - Herbário do Instituto de Botánica Darwinion, San Isidro, Buenos Aires, Província de Buenos Aires, Argentina;

SMDB - Herbário do Departamento de Biologia da Universidade Federal de Santa Maria, Santa Maria, RS, Brasil;

- Herbário Particular de Karner Hagelund, Arroio dos Ratos, RS, Brasil.

A descrição do gênero é baseada em Hutchinson (1964) e Allen \& Allen (1981).

A identificação das espécies, apoiada fundamentalmente na morfologia, foi baseada nas obras de BENTHAM (1859) e BURKART (1942), comparando-se as descrições originais com material herborizado.

A descrição das espécies baseou-se no material estudado. A terminologia da morfologia foliar e indumento foi a de HICKEY (1974) e RADFORD (1974) e as medidas representam os extremos observados.

A ocorrência no Estado é de acordo com as regiões fisiográficas (Figura 1), baseada em coletas e dados de exsicatas. Para cada espécie é fornecido um mapa (Figuras 2 e 3 ), onde estão assinaladas as localidades de coleta, por municípios, excluindo-se espécimes coletados em outros estados e países.

Um número significativo de exsicatas foram analisadas mas, por questões práticas, a lista de espécimes citados é apenas representativa e restrita ao Rio Grande do Sul. Lista completa de materiais examinados pode ser obtida com o autor. 


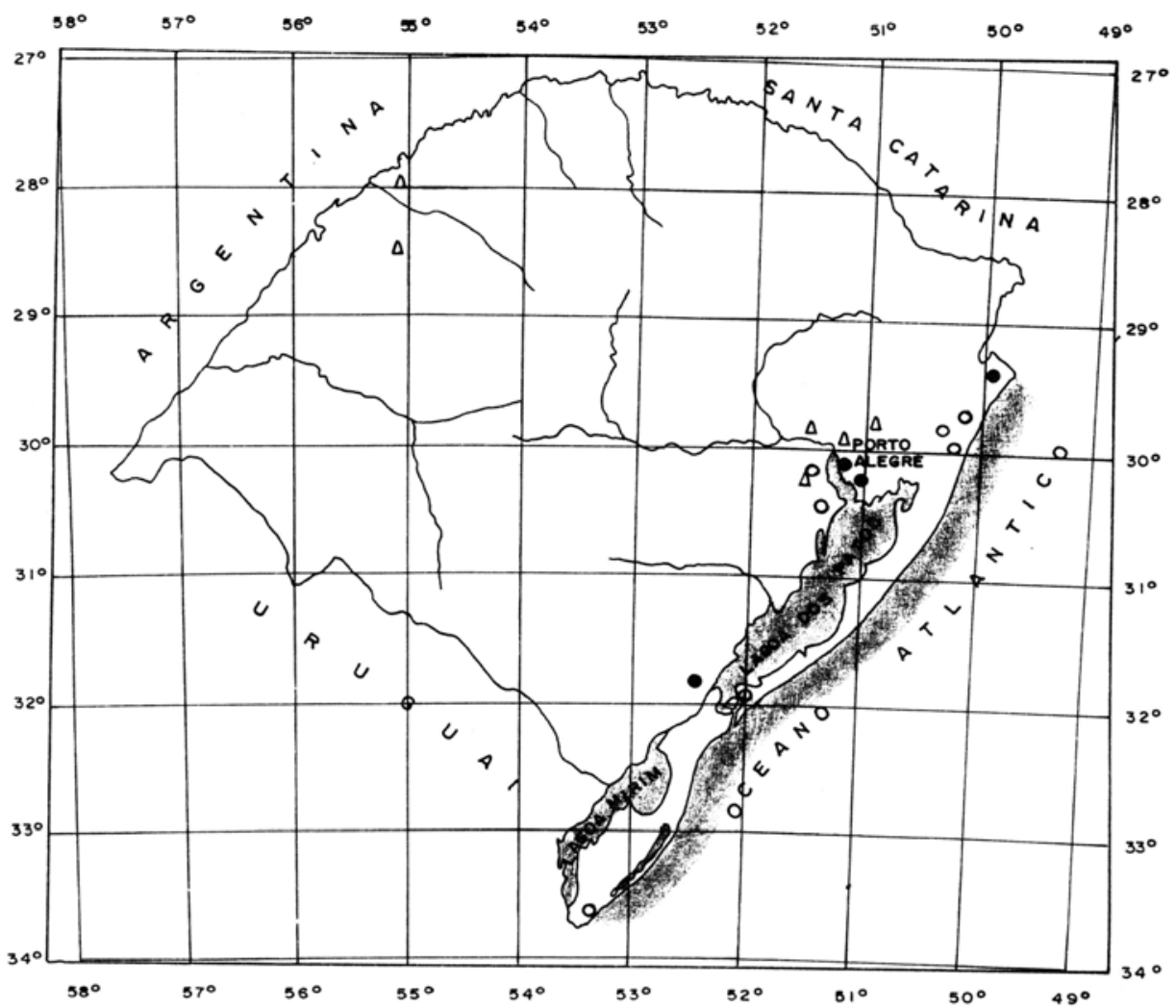

LEGENDA:

O- - s. sobulicolo

$\Delta-\underline{I}$. sutfruticoso

- I. suffruticoso I. Iabulicolo

2. Distribuição de Indigofera sabulicola Benth. e I. suffruticosa Mill. no Rio Grande do Sul.

Não adotamos níveis taxonômicos infra-específicos no presente trabalho, uma vez que as espécies analisadas apresentam uma variação morfológica contínua. Consideraram-se os espécimes analisados como representantes de uma mesma populaçâo, com indivíduos intermediários entre as formas extremas. 


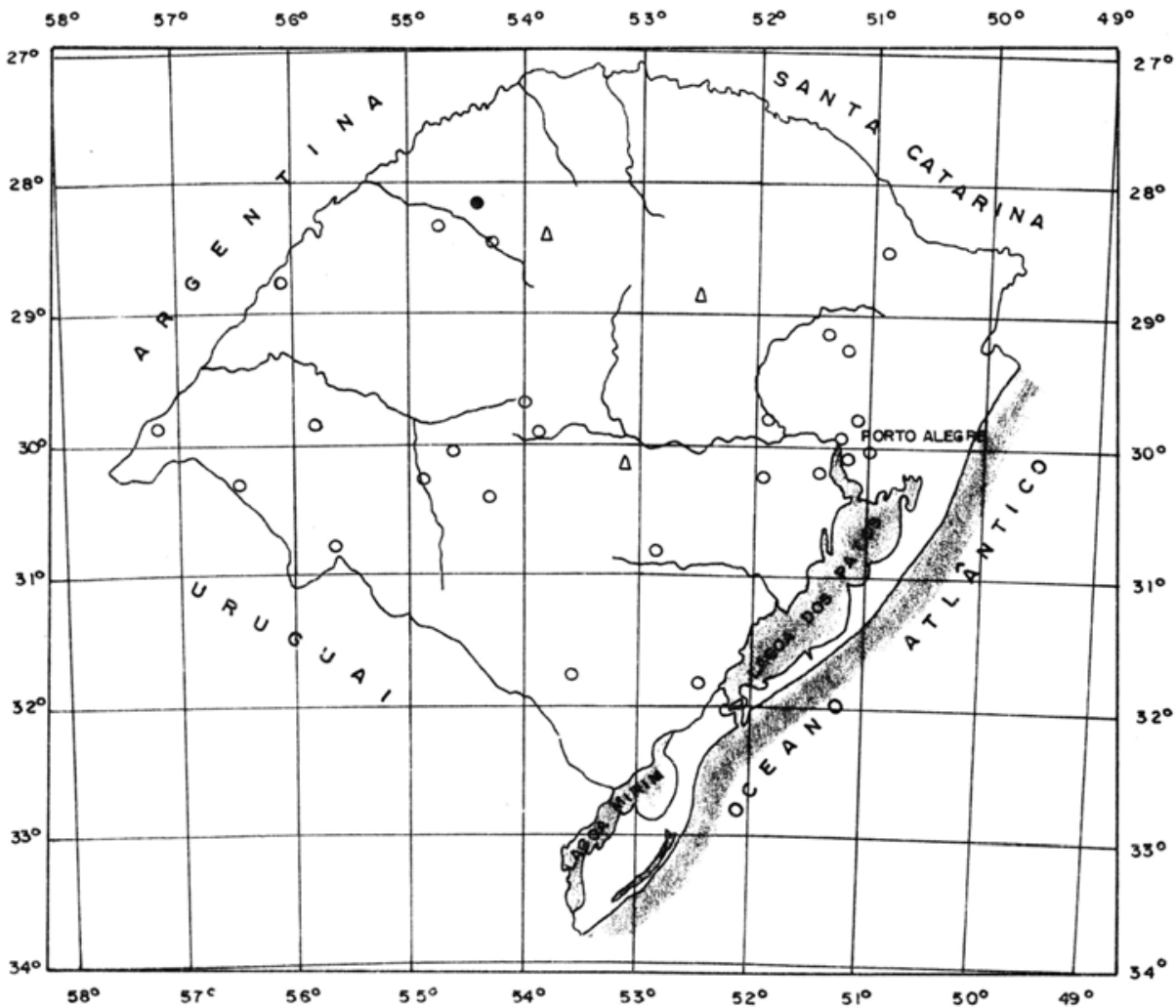

\section{LEGENDA:}
$0-I$. asporifolio
$\Delta-\underline{I}$. compastris
- I. osperifolio - I. compestris

3. Distribuição de Indigofera asperifolia Bong. e I. campestris Bong. no Rio Grande do Sul.

\section{Resultados}

Indigofera L. Spc. Plant. 2: 751, 1973.

Sphaeridiophorum Desv. Journ. Bot. 6(3): 123, 1813.

Brissonia Desv. Journ. Bot. I: 78, 1814 in Ann. Sc. Nat. Ser. I IX: 411, 1896.

Hemispadon Endl. 1. c. XV: 385, 1832.

Oustropis G. Don Gen. Syst. II: 214, 1832.

Tricoilendus Rafin. Fl. Tellur. II: 97, 1836.

Eilemanthus Hochst. in Flora XXIX: 593, 1846.

Amecarpus Benth. in Lindl. Veg. Kingd: 554, 1847. 
Acanthonotus Benth. in Hock. Niger Fl.: 293, 1849.

Indigastrum Jarub. \& Spach, Illustr. V 101. t 492, 1857.

Arbustos, subarbustos ou ervas anuais ou perenes, inermes, cobertos com pêlos malpiguiáceos, às vezes, misturados com outro tipo de indumento. Folhas alternas, imparipinadas, trifolioladas, mais raramente pinado-trifolioladas ou unifolioladas. Folíolos inteiros, opostos ou alternos, às vezes com estipelas. Estípulas freqüentemente pequenas, setáceas, base levemente adnata ao pecíolo. Flores em rácemos ou espigas axilares ou terminais, pedunculadas ou sésseis. Brácteas pequenas, caducas ou nulas. Cálice pequeno, campanulado, com cinco lacínias subiguais, triangulares, lanceoladas ou subuladas, as inferiores freqüentemente maiores, pubescentes ou glabras. Corola pequena, vermelha, rósea ou púrpura. Estandarte séssil ou unguiculado, reflexo, glabro ou pubescente do lado externo. Alas levemente aderidas à carena. Carena obtusa a acuminada, calcarada em ambos os lados. Androceu diadelfo. Estame vexilar totalmente livre. Anteras uniformes, elípticas, com conetivo apiculado, glandular. Ovário séssil a subséssil, óvulos 1-2 a numerosos. Estilete glabro, ápice arqueado. Estigma apical, capitado, freqüentemente penicilado. Frutos lineares a globosos, estreitos, retos ou arqueados, reflexos, raramente circinados, cilíndricos, com 3-4 faces achatadas, com pseudosseptos entre as sementes. Sementes pequenas globosas, cilíndricas ou cubóides, albuminadas, estrofioladas. Hilo lateral, circular, pequeno. Germinação epígea.

$2 \mathrm{n}=14,16,32,48$.

As espécies estudadas pertencem à secção Indigofera, série Pinnatae, de acordo com TAUBERT (1894).

O gênero Indigofera é de fácil reconhecimento pela presença de pêlos malpiguiáceos e anteras com glândulas apicais.

$\mathrm{E}$ fonte do corante azul índigo, já usado, desde aproximadamente 2.300 A.C. pelos egípcios para tingir os tecidos usados na mumificação (ALLEN \& ALLEN, 1981). O cultivo de índigo foi comum na América em épocas passadas, inclusive no Brasil (PIO CORREA, 1926), desaparecendo com o surgimento do corante sintético.

Chave para as espécies de Indigofera estudadas

A - Folíolos glandulosos na face dorsal

A - Folíolos sem glândulas.

B - Folíolos sempre opostos.

Fruto marcadamente curvo ............................. 2. I. suffruticosa Mill.

B - Folíolos alternos, raramente opostos. Fruto reto.

C - Pilosidade adpressa. Pêlos com braços de mesmo comprimento, estendidos. Folíolos lineares, estreito elípticos a elípticos

1. I. sabulicola Benth.

C- Pilosidade vilosa tendendo a estrigosa. Pêlos com
braços desiguais mais ou menos erguidos. Folíolos 3. I. asperifolia Bong. oblongos, obovados a elípticos 4. I. campestris Bong. 
1. Indigofera sabulicola Benth. in Mart. Fl. Bras. 15(1): 40, 1859

Subarbusto perene, hemicriptófito, prostrado a ascendente, freqüentemente apresentando xilopódio. Partes jovens cinéreo-seríceas, pêlos malpiguiáceos mais ou menos erguidos, tendendo a estrigosos.

Folhas imparipinadas, $2-3 \mathrm{~cm}$ de compr. Estípulas $3-4 \mathrm{~mm}$ de compr., opostas, estreito-subuladas, pubescentes, com glândulas esféricas, caducas. Pecíolo $0,5 \mathrm{~cm}$ de compr., pubescente. Ráquis $1,7-2,2 \mathrm{~cm}$ de compr. Estipelas diminutas, aciculares, escuras, às vezes caducas. Folíolos $5-12 \mathrm{~mm}$ de compr. por $2-6 \mathrm{~mm}$ de larg., o terminal às vezes pouco maior, em número de 5-11 opostos, obovados, obovado-elípticos, ápice obtuso, mucronado, concolores, cartáceos quando secos, com pêlos oblíquos à nervura central, em ambas as faces, às vezes subglabros, na face dorsal com glândulas numerosas, esféricas, amarelo-alaranjadas.

Rácemos 2,5-6cm de compr., axilares, eretos, na maioria das vezes maiores do que as folhas, floridos na metade superior. Pedúnculo e ráquis floral pubescentes. Brácteas $2 \mathrm{~mm}$ de compr., triangulares, pubescentes, glandulosas.

Flores 5-7mm de compr. Pedicelos $1 \mathrm{~mm}$ de compr., densamente pubescentes. Cálice campanulado, 3-4mm de compr., seríceo-pubescente, com 5 lacínias triangulares, 2-3 vezes maiores do que o tubo, subiguais, as superiores mais largas, glândulas esféricas, caducas, ao longo das nervuras centrais; cálice parcial ou totalmente persistente no fruto. Corola rosa ou lilás, caduca. Estandarte 6-7mm de compr., obovado; ápice retuso, longamente unguiculado, externamente seríceo-pubescente. Alas 7-8mm de compr., oblongas, ápice dilatado e assimétrico, parcialmente presas à carena, auriculadas, unguiculadas, ciliadas no ápice e na base. Peças da carena $6-8 \mathrm{~mm}$ de compr., lanceoladas, um pouco dilatadas na metade superior, ápice obtuso, ciliado, cuculadas na região mediana. Ovário reto, séssil, multiovulado, com pêlos esparsos na ântese, após a fecundação, tomentoso. Estilete curvo, glabro. Estigma terminal, capitado.

Legume $8-12 \mathrm{~mm}$ de compr. por 1-2mm de larg., subcilíndrico, levemente curvo, reflexo, pubérulo, ápice finamente aristado, com pseudosseptos internos. Aparentemente indeiscente.

Sementes aproximadamente $1 \mathrm{~mm}, 4-7$ por fruto, raramente menos, amareladas, cubóides a orbiculares; hilo central, esférico. Figura 4.

Habitat: solos arenosos, secos ou úmidos.

Floração: outubro - março.

Frutificação: novembro - abril.

Ocorrência no Estado: Litoral, Depressão Central e Encosta do Sudeste (Figura 2).

Distribuição geral: América tropical, desde o México até o nordeste da Argentina (BURKART, 1942).

Material representativo:

BRASIL - RIO GRANDE DO SUL - Capão da Canoa, Atlântida, /II/1978, Pfadenhauer 264 (ICN-47363) - Osório, 9/XI/1934, J. Dutra 785 (ICN 14785) - Tramandaí, 12/II/1933, B. Rambo 373 (PACA 373); Imbé, 19/III/1983, S. Eisinger s/n ${ }^{\circ}$ (ICN 53410) - Rio Grande, /II/1965, I. Barreto s/n' (BLA 4690) - Torres, s/data, D. Boeira s/n ${ }^{\circ}$ (IPRN) - Porto Alegre, Praia de Belas, 24/X/1967, A.G. Ferreira 331 (ICN 4555). 

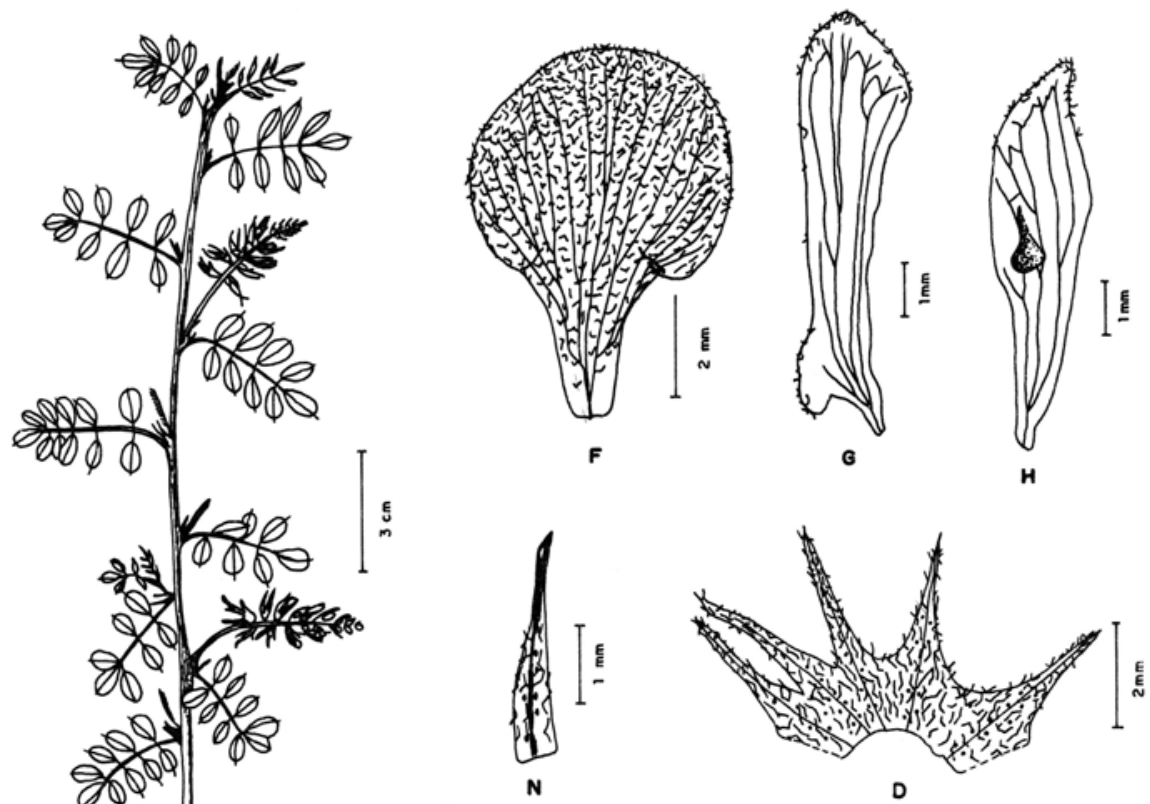

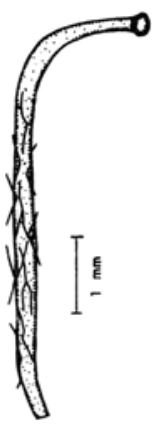

B

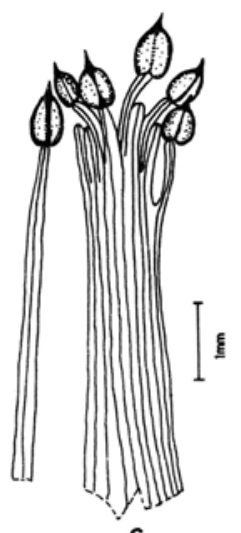

c

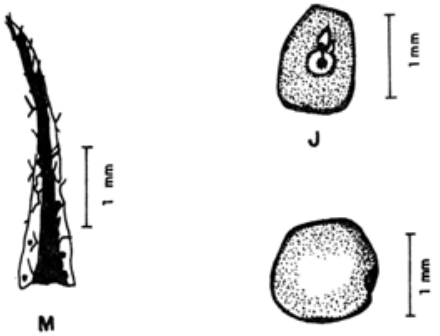

ᄂ

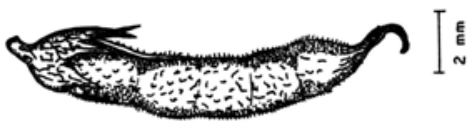

I

\section{Legenda das figuras 4 a 7}

A - Hábito; B - Gineceu; C - Androceu; D - Cálice, vista dorsal; E - Cálice, androceu e gineceu; F - Estandarte, vista dorsal; G - Ala esquerda, vista dorsal; H - Carena esquerda, vista dorsal; I - Fruto; J - Semente, vista ventral; L - Semente, vista lateral; M - Estípula; $\mathrm{N}$ - Bráctea.

4. Indigofera sabulicola Benth. - S. Eisinger s/n. (ICN 53410); Hábito: A.G. Ferreira 331 (ICN 4555). 
2. Indigofera suffruticosa Mill. Gard. Dict. ed. $8 n^{\circ} 2,1768$

Indigofera uncinata G. Don Gard. Dict. 2: 208

I. anil Mant. Plant.: 272, 1771

Anilla tinctoria (L.) O.K. Rev. Gen. 1: 160, 1891

I. micrantha Desv. Ann. Sc. Nat. Par. Sér. I - 9: 410

Subarbusto ou arbusto perene, ereto, até $1,5 \mathrm{~mm}$ de alt. Todo o vegetal adpresso-pubescente nas regiōes jovens. Pêlos malpiguiáceos completamente estendidos, tendendo a estrigosos.

Folhas $5-10 \mathrm{~cm}$ de compr., parcialmente caducas. Estípulas $2-4 \mathrm{~mm}$ de compr., opostas, estreito-subuladas, parcialmente concrescidas na base com o pecíolo, pubescentes, às vezes caducas. Pecíolo $1-2 \mathrm{~cm}$ de compr., pubescentes. Ráquis sulcada, pubescente. Estipelas diminutas, aciculares, escuras, às vezes caducas. Folíolos laterais $1,2-2,5 \mathrm{~cm}$ de compr. por $0,3-1 \mathrm{~cm}$ de larg., terminais 1,3-2,5cm de compr. por 0,5-1,2cm de larg., 7-1,5, opostos, elípticos, oblongos ou obovados; ápice obtuso ou agudo, mucronado; base aguda; os terminais um pouco mais obovado que os laterais; discolores, cartáceos quando secos, face ventral subglabra a glabra, face dorsal com pêlos oblíquos à nervura central; pilosidade estrigosa.

Rácemos 1-4,5cm de compr., axilares, eretos, menores do que as folhas, densos, floridos desde a base. Pedúnculo curvo, pubescente. Ráquis floral pubescente, angulosa, Brácteas 1-2mm de compr., subuladas, levemente convexas, com pêlos curtos, caducas.

Flores 4-5mm de compr. Pedicelos até $1 \mathrm{~mm}$ de compr., densamente pubescentes. Cálice 1-1,5mm de compr., campanulado, com 5 lacínias curtas, triangulares, agudas, subiguais, as superiores mais curtas, pubescentes, persiste parcial ou totalmente no fruto. Corola de cor variada: azul, lilás, rosa ou alaranjada, caduca após a ântese, 3-4 vezes maior do que o cálice. Estandarte 3,5-4mm de compr., orbicular, unguícula mínima, densamente pubescente do lado externo. Alas $3,5 \mathrm{~mm}$ de compr., oblongas, ápice assimétrico, às vezes ciliado. Peças da carena $4 \mathrm{~mm}$ de compr., oblanceoladas, cuculadas na região mediana; aurículas pouco desenvolvidas, pubescentes na metade superior ventral. Ovário linear, às vezes levemente curvo, subglabro na ântese, pluriovulado. Estilete curvo, glabro. Estigma apical, capitado.

Legume $2 \mathrm{~cm}$ de compr. por $2 \mathrm{~mm}$ de larg., subcilíndrico, marcadamente curvo, com a concavidade voltada para cima, com pseudosseptos, ápice mucronado, pubérulo; deiscência tardia.

Sementes 4-7 por fruto, 1,5-2,5mm, acinzentadas, marmoreadas, tendendo a cubóides; hilo esférico, escuro. Figura 5.

Nome popular: anil, anileira, erva-de-anil.

Habitat: beira de estradas, campos arbustivos e locais alterados.

Floração: todo o ano, mais intensa na primavera-verão.

Frutificação: provavelmente o ano todo; não registrada em abril, setembro e outubro.

Ocorrência no Estado: Depressão Central, Encosta Inferior do Nordeste, Litoral, Encosta do Sudeste, Alto Uruguai e Missões. Figura 2. 


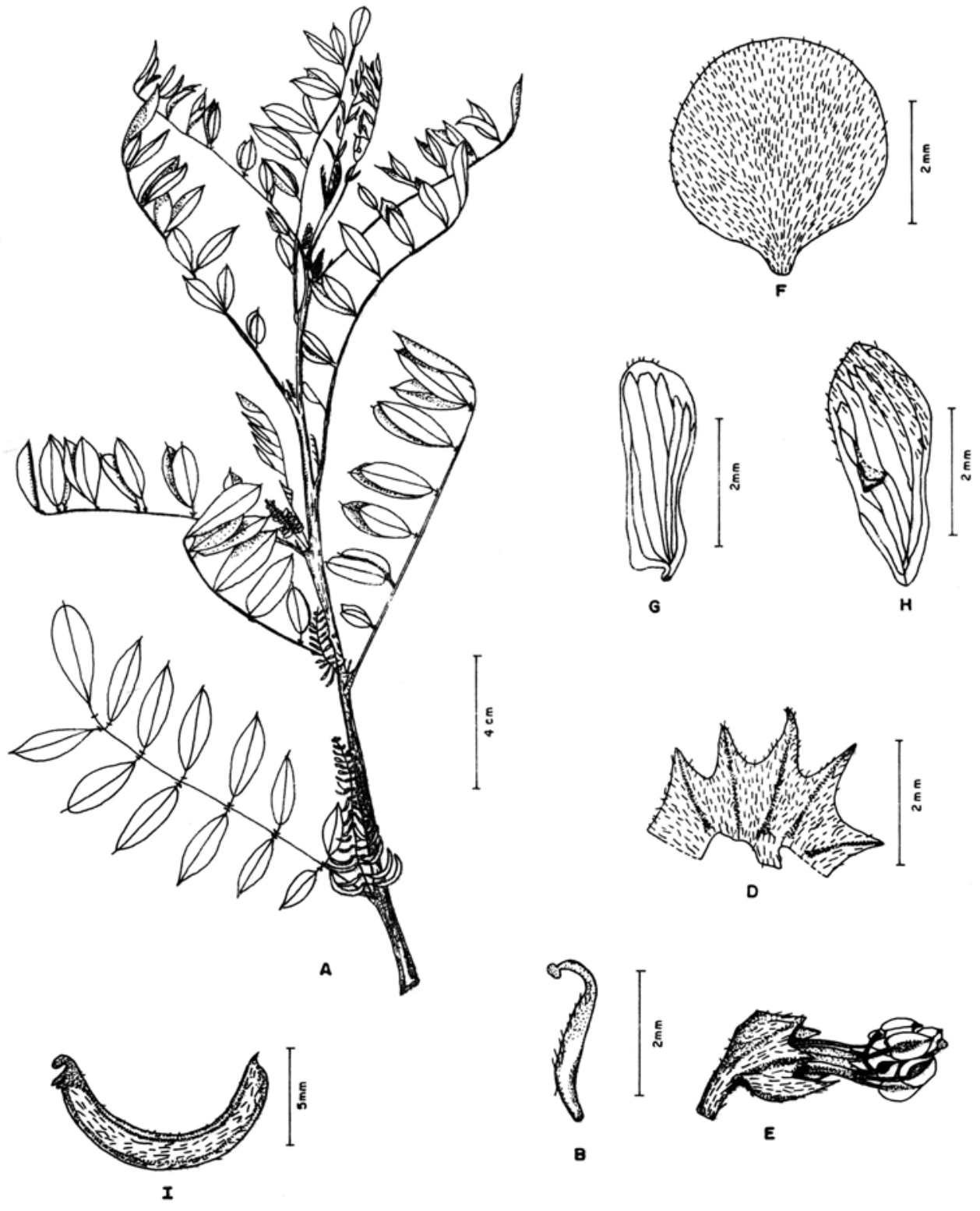

5. Indigofera suffruticosa Mill. - S. Eisinger $\mathrm{s} / \mathrm{n}^{\circ}$ (ICN 51925). 
Distribuião geral: América tropical e subtropical (BURKART, 1942). Material representativo:

BRASIL - RIO GRANDE DO SUL - Guaíba, Est. Exp. Agron., 20/V/1972, H. Longhi-Wagner 61 (ICN 23938) - Porto Alegre, Morro da Polícia, 5/XI/1932, B. Rambo 376 (PACA 376) - Taquara, RS 020, 26/III/1981, S. Eisinger s/no (ICN 51925) - Pelotas, Laranjal, 07/III/1956, J.C. Sacco 256 (PACA, PEL 1380).

3. Indigofera: asperifolia Bong. ex Benth. in Ann. Nat. Hist. Sér. 1-3: 431, 1839

I. retrusa Brown in J.G. Kerr. en Trans. Proceed. Bot. Soc. Edinb. 20(1): 51, 1894.

Subarbusto perene, hemicriptófito, com xilopódio bastante desenvolvido. Prostrado a ascendente. Planta áspera ao tato. Pêlos malpiguiáceos adpressos, estendidos, conferindo aos ramos e folhas coloração cinérea, raramente amarelada. Nas porções jovens da planta pilosidade mais densa, em direção à base, subglabro a glabro.

Folhas alternas, imparipinadas, $2,5-5,5 \mathrm{~cm}$ de compr., geralmente com mais de três folíolos, mas também pinado-trifoliolados, ou digitado-trifolioladas. Estípulas $2-5 \mathrm{~mm}$ de compr., subuladas ou setáceas, base parcialmente concrescida com pecíolo, pubescentes. Pecíolo até $5 \mathrm{~mm}$ de compr., pubescente, às vezes quase nulo. Ráquis pubescente. Estipelas diminutas, aciculares, escuras, às vezes caducas ou nulas. Folíolos 3-9, 9-27mm de compr. por 1-4,5mm de larg., o terminal um pouco maior, geralmente alternos, raramente opostos, lineares, estreito-elípticos a elípticos, ápice agudo a obtuso, mucronado, base aguda, pilosidade nas duas faces com predomínio na dorsal, discolores, às vezes cartáceoscoriáceos, quando secos.

Rácemos $5-40 \mathrm{~cm}$ de compr., axilares, eretos, multifloros, excedendo às folhas, às vezes truncados, densos no ápice, laxos em direção à base. Pedúnculo $33-8 \mathrm{~cm}$ de compr., pubescente. Ráquis floral cinérea, angulosa. Brácteas $2-5 \mathrm{~mm}$ de compr., setáceas, às vezes cimbiformes, pubescentes, na maioria das vezes caducas.

Flores 6-10mm de compr. Pedicelo em torno de $1 \mathrm{~mm}$ de compr., densamente pubescente. Cálice $3-5 \mathrm{~mm}$ de compr., campanulado, persistente, pubescente, 5 lacínias subiguais, longas, triangulares a subuladas, 2-3 vezes o tamanho do tubo. Corola rosada, lilás ou roxa, caduca, no botão densamente pubescente. Estandarte 6-9mm de compr., obovado, orbicular ou rômbico, pilosidade na face externa não atingindo a região basal, às vezes ápice obtuso, unguícula curtíssima. Ala $6-9 \mathrm{~mm}$ de compr., dilatadas na região superior, ápice obtuso ou atenuado, com ou sem cílios, aurículas próximas à base, às vezes quase nulas. Peças da carena $6-8 \mathrm{~mm}$ de compr., alargadas na região central, às vezes tendendo a falciformes, cuculadas na região mediana, ápice agudo, unguícula espessa. Ovário reto, subglabro, séssil, multiovulado. Estilete curvo, glabro. Estigma apical, capitado. 

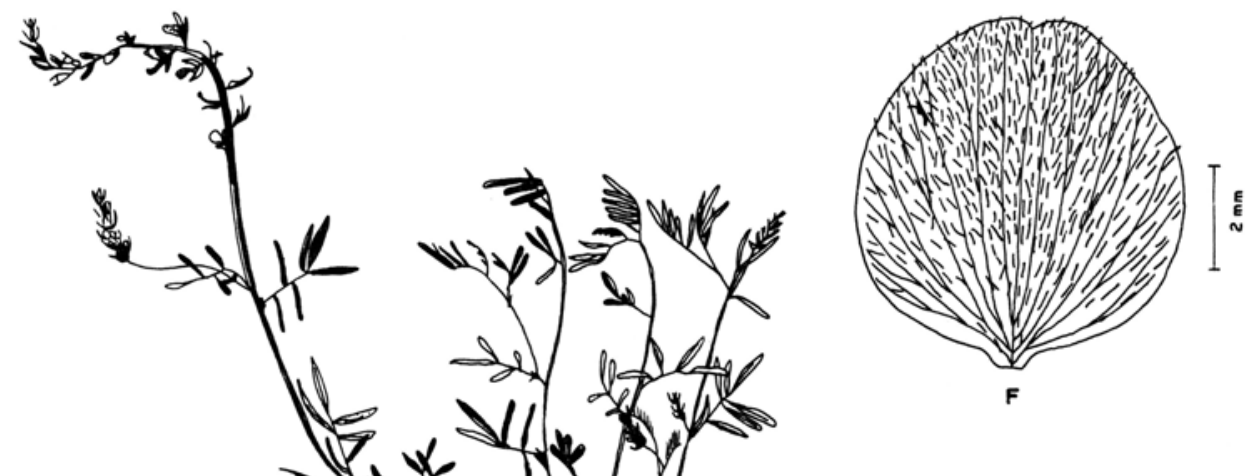

(

M

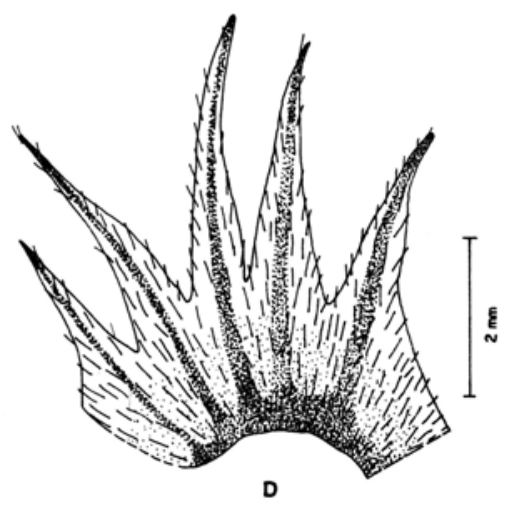

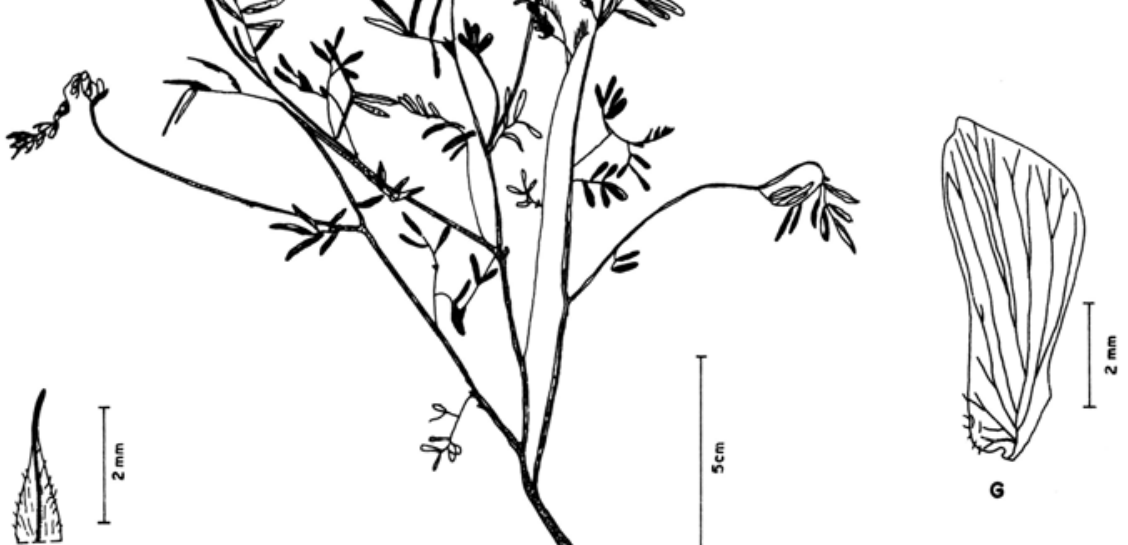
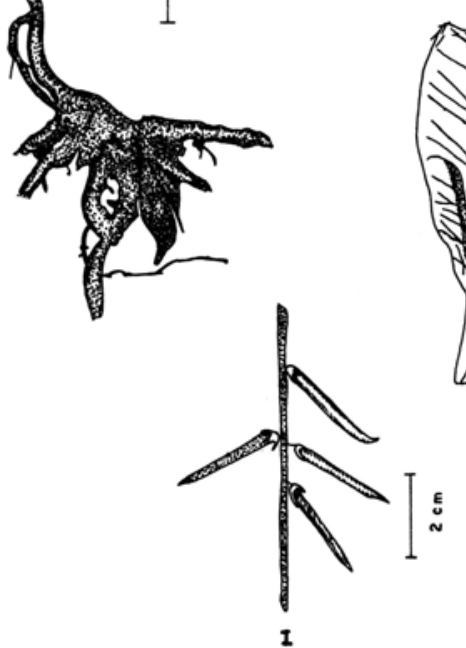

6. Indigofera asperifolia Bong. - S. Eisinger $s / n^{\circ}$ (ICN 53696); Fruto: B. Rambo 53027 (PACA 53027). 
Legume $2-3 \mathrm{~cm}$ de compr. por $3 \mathrm{~mm}$ de larg., subcilíndrico, reto, reflexo, com suturas evidentes, pubérulo ou glabro; pseudosseptos; ápice mucronado. Deiscência tardia ou provavelmente nula.

Sementes, aproximadamente $2 \mathrm{~mm}$, 6-9 por fruto; hilo oblongo a esférico. Figura 6.

Habitat: solos arenosos, pedregosos e morros graníticos.

Floração: outubro a fevereiro.

Frutificação: novembro a dezembro.

Ocorrência no Estado: todas as regiões com exceção do Litoral. Figura 3.

Distribuição geral: Brasil austral, Paraguai, Uruguai, Bolívia e nordeste da Ar-

Material representativo: gentina (BURKART, 1942).

BRASIL - RIO GRANDE DO SUL - Cacequi, Sangão do Macaco Branco, 27/IX/1983, S. Eisinger 1 e 2 (ICN 53961 e 53964) - Porto Alegre, s/data, B. Rambo s/n ${ }^{\circ}$ (ICN 14715) - Santo Ângelo, 17/XI/1952, B. Rambo 53027 (PACA 53027) - Caxias do Sul, Vila Manresa, B. Rambo 29129 (PACA 29129).

\section{Indigofera campestris Bong. ex Benth., in Mart. Fl. Bras. 15(1): 38, 1859}

Subarbusto perene, prostrado a ascendente, hemicriptófito, levemente áspero ao tato, partes jovens da planta densamente cinéreo-pubescentes. Pêlos malpiguiáceos de braços desiguais, erguidos. Pilosidade vilosa tendendo a estrigosa, amarela-clara, de densidade variável.

Folhas alternas, imparipinadas, $2,5-5,5 \mathrm{~cm}$ de compr. Estípulas $4-9 \mathrm{~mm}$ de compr., opostas, triangulares a subuladas. Pecíolos pubescentes, até $5 \mathrm{~mm}$ de compr. ou nulos. Ráquis pubescentes. Estipelas aciculares, escuras, caducas ou nulas. Folíolos 11-22mm de compr. por 4-10mm de larg., 3-8, alternos, oblongos, obovados ou elípticos, ápice e base variável, freqüentemente mucronados, concolores, cartáceos quando secos, pilosidade nas duas faces, mais densa na dorsal.

Rácemos 7-21cm de compr., axilares, eretos, truncados, mais longos que as folhas, multifloros, floridos a partir da metade superior. Pedúnculo e ráquis floral pubescentes, de aspecto freqüentemente cinéreo. Brácteas triangulares, subuladas ou rômbicas, $33-5 \mathrm{~mm}$ de compr., pubescentes, caducas.

Flores $8-13 \mathrm{~mm}$ de compr. Pedicelos até $2 \mathrm{~mm}$ de compr., pubescentes. Cálice 4-5mm de compr., campanulado, pubescente, lacínias desiguais, triangulares a subuladas, de até duas vezes o tamanho do tubo, persistentes parcialmente no fruto. Corola rosada ou salmão. Estandarte 7,5-10mm de compr., obovado oblongo-obovado ou largo-rômbico, unguícula curta, na maioria das vezes glabro externamente, raramente com pêlos em torno da linha mediana. Alas $8,5-12 \mathrm{~mm}$ de compr., quase oblongas, às vezes dilatadas na metade superior, cílios curtos próximo à base ou nulos, aurículas pequenas. Peças da carena $7-10 \mathrm{~mm}$ de compr., agudas, menores que as alas, oblongas ou estreito-rômbicas, levemente falcadas, cuculadas na região mediana, aurícula sempre presente, curtamente ciliadas. Ovário séssil, reto, glabro, 7-11 ovulado. Estilete curvo, levemente estreitado em direção ao ápice, glabro. Estigma apical, capitado. 

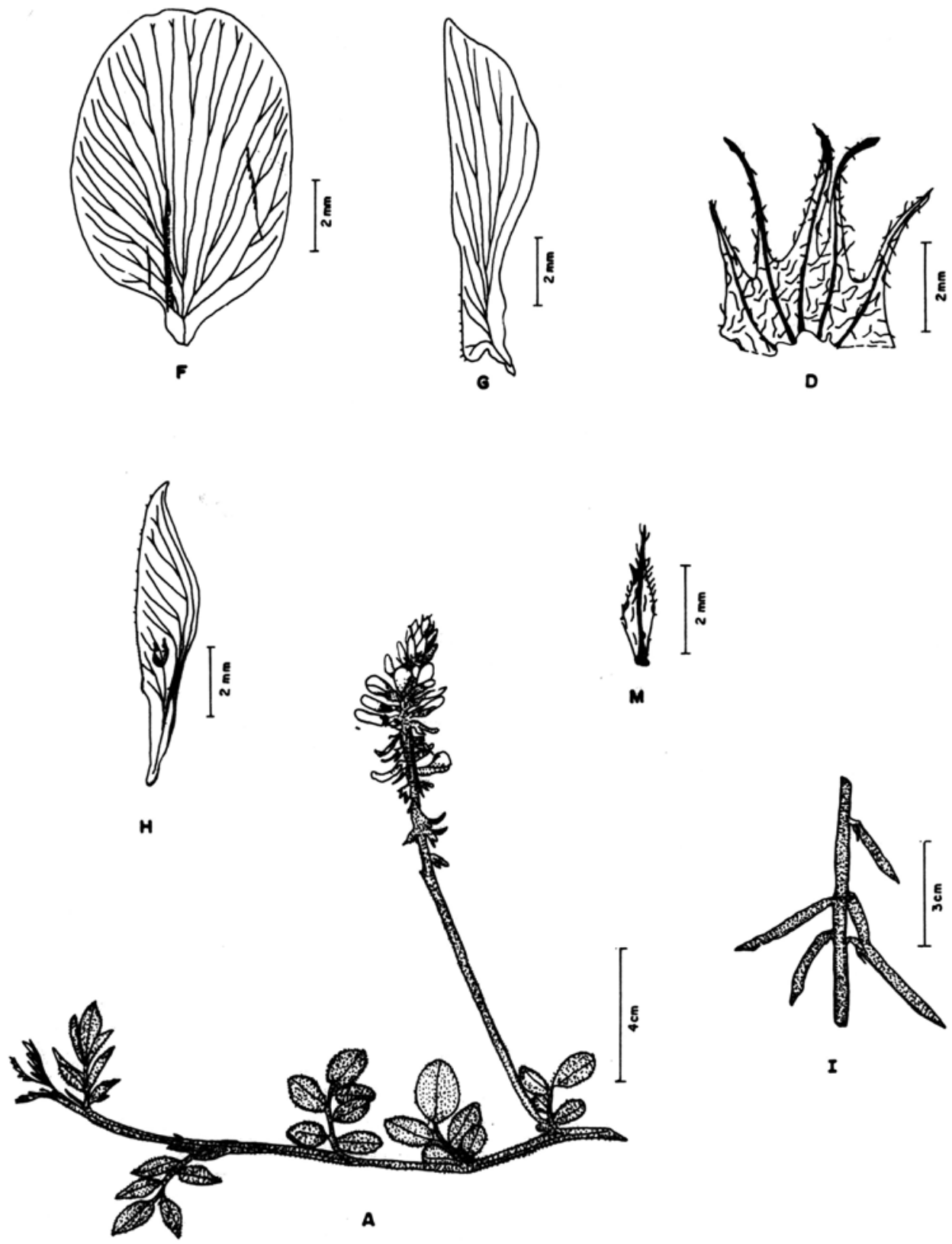

$\mathbf{I}$

7. Indigofera campestris Bong. - K. Hagellund 1172; Fruto: B. Rambo 60312 (PACA 60312). 
Legume 2,3-3,1 cm de compr. por 2,5-3mm de largura., subcilíndrico, reto, reflexo, com suturas bem marcadas, ápice atenuado, pubérulo; provavelmente, indeiscente.

Sementes 4-10 por fruto, cubóides a rômbicas, aproximadamente $1,5 \mathrm{~mm}$. Hilo central, esférico ou oblongo. Figura 7.

Habitat: campos secos e barrancos.

Floração: outubro-novembro.

Frutificação: novembro-janeiro.

Ocorrência no Estado: Planalto Médio, Alto Uruguai e Depressão Central. Figura 3.

Distribuição geral: Brasil, Paraguai, Bolívia e noroeste da Argentina (BURKART, 1942).

Material representativo:

BRASIL - RIO GRANDE DO SUL - Soledade, 18/X/1970, B. Irgang s/n ${ }^{\circ}$ (ICN 7818) - Ijuí, NWH, 8/I/1957, B. Rambo 60312 (PACA 60312) - Cachoei-

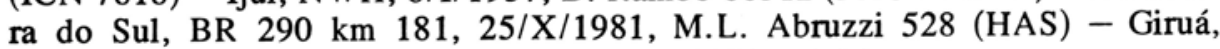
Granja Sodal, /X/1963, K. Hagelund 2577, 2578 e 1172.

\section{Discussão e conclusões}

Indigofera sabulicola é uma espécie psamófila muito característica pelas glândulas presentes tanto nas partes vegetativas quanto nas florais. É uma espécie muito próxima a $I$. microcarpa Desv. que também apresenta glândulas, mas à primeira vista diferencia-se pela densa pilosidade que ostenta e que confere um aspecto esbranquiçado à planta e aos frutos. Também, o número de sementes nesta espécie é no máximo 4 por fruto.

I. sabulicola é encontrada em toda a faixa litorânea, freqüentemente acompanhada de Axonopus parodii Valls. BURKART $(1943,1952)$ cita a espécie como fixadora de dunas e BARRETO \& KAPPEL (1967) a consideram uma forrageira regular, de campos baixos.

Uma característica marcante de $I$. suffruticosa são os frutos curvos. Esta espécie é freqüentemente encontrada nas beiras de estrada e locais abandonados. Segundo STANDLEY (1920-26 e 1930), é empregada na medicina popular como antitérmico, purgativo, diurético, tônico, para zombater abscessos, picadas de cobras, de abelhas e de outros insetos. PIO CORREA (1926) acrescentou ainda o uso da mesma no combate à icterícia; as folhas são usadas nas afecçöes do sistema nervoso e a raiz é odontálgica. Também seria antídoto do mercúrio e do arsênico.

BARRIOS \& GONZALEZ (1971) constataram que os nódulos bacterianos da espécie são arredondados a alongados. De acordo com ALLEN \& ALLEN (1981), no norte do Brasil, $I$. suffruticosa é usada como ictiotóxica.

I. suffruticosa apresenta-se provavelmente bem distribuída no Rio Grande do Sul e está presente em 6 das 11 regiões fisiográficas do Estado.

I. asperifolia foi a espécie que apresentou a amplitude de variação morfológica qualitativa e quantitativamente mais acentuada. Tal variação é observada 
tanto nas porções végetativas quanto nas flores (EISINGER, 1985). O caráter mais constante é a pilosidade adpressa.

Na Figura 3 está representado um indivíduo com folíolos lineares, típico dos solos secos da Campanha e morros graníticos dos arredores de Porto Alegre, onde é freqüente. Tal indivíduo é um repreșentante da variedade típica da espécie (var. asperifolia), segundo'BURKART (1942), encontrada no Rio Grande do Sul e em Misiones. Formas mais robustas são referidas pelo mesmo autor como sendo transições entre esta espécie e a sua vizinha, I. campestris. Isto ficou muito evidente após examinarmos grande número de exsicatas dessas duas espécies, procedentes de diversos locais.

I. asperifolia a a espécie mais amplamente distribuída no Estado, estando ausente apenas no Litoral.

BARRETO \& KAPPEL (1964) citam a espécie como forrageira regular, de campos pedregosos. Os nódulos bacterianos foram observados pela primeira vez por BARRIOS \& GONZALEZ (1971) e são arredondados.

I. campestris tem distribuição bastante restrita no Estado, razão pela qual não foi coletada por nós. Todos os exemplares analisados foram oriundos de herbários, onde freqüentemente estava confundida com a espécie anterior. Diferencia-se de $I$. asperifolia pela pilosidade vilosa; pêlos erguidos, um pouco torcidos e com braços desiguais.

É uma espécie crítica, pelo seu polimorfismo associado à sua ampla distribuição geográfica (BURKART, 1942 e HASSLER, 1910). Os exemplares nativos assemelham-se com o tipo, Riedel 548, principalmente na forma e tamanho dos folíolos. Já os exemplares argentinos apresentam folíolos maiores e mais alongados, como referido por BURKART (1942) e por nós observado.

HASSLER (1910), analisando uma população de $I$. campestris, ressaltou o polimorfismo foliar desta espécie observando que à medida que o número de folíolos diminui, aumenta o tamanho do folíolo terminal, até o extremo, representado por indivíduos unifoliolados, que corresponderiam a I. latifolia Mich. O autor criou inúmeras variedades e formas para cada uma das expressões morfológicas encontradas. $\mathrm{O}$ nosso material se assemelha muito à variedade campestris.

\section{Agradecimentos}

Aos colegas Luis R.M. Baptista e Silvia T.S. Miotto, pelas sugestões e incentivo durante a realização do trabalho. 


\section{Referências bibliográficas}

ALLEN, O.N. \& ALLEN, E.K. 1981. The Leguminosae: a source book of characteristics, uses and nodulation. University of Wisconsin Press. Wisconsin.

BARRETO, I.L. \& KAPPEL, A. 1964. Principais espécies de gramíneas e leguminosas das pastagens naturais do Rio Grande do Sul. In: Anais Congresso Nacional de Botânica. 15., Porto Alegre.

BARRIOS, S. \& GONZALEZ, V. 1971. Rhizobial symbiosis on Venezuelan sanavas. Plant Soil, 34 (3): 707-19.

BENTHAM, G. 1859. Leguminosae. I. Papilionaceae. In: MARTIUS, C.F.P. Flora Brasiliensis. v.15, pt.1.

BENTHAM, G. 1865. Leguminosae. In: BENTHAM, G. \& HOOKER, J.D. Genera Plantarum. I.L. Reeve. London. v.1, pt.2.

BORNMULleR, Von J. 1934. Florula Riograndensis. Rev. Sudamer. Bot., 1 (5): 129-48.

BURKART, A. 1942. Las espécies de Indigofera de la flora argentina. Darwiniana, 4 (2-3): 145-78.

BURKART, A. 1943. Las leguminosas argentinas - silvestres y cultivadas. Acme. Buenos Aires.

BURKART, A. 1952. Las leguminosas argentinas - silvestres y cultivadas. 2: ed. Acme. Buenos Aires.

EISINGER, S.M. 1985. Polimorfismo em Indigofera asperifolia Bong. In: Anais Congresso Nacional de Botânica. $36^{\circ}$, Curitiba.

ENGLER, A. \& GILG, E. 1924. Syllabus der pflanzenfamilien. Gebrüder Borntrager. Berlin.

HASSLER, E. 1910. Polymorphism foliaire chez Indigofera campestris Bong. Bull. Soc. Genève ser. $2,2: 32-6$.

HICKEY, L.J. 1974. Clasificación de la arquitectura de las hojas de dicotiledónes. Bol. Soc. Arq. Bot., 16 (1-2): 1-25.

HUTCHINSON, J. 1964. The genera of flowering plants. Oxford University. London. v.1.

LINDMAN, C.A.M. 1898. Leguminosae austro-americanas. Bih. Till Svenska Vet. - Akad., 24 (7): 6-7.

LINNAEUS, C. 1959. Species Plantarum. The Ray Society. London (Facsimile, 1753).

LUIS, T. 1960. Flora analítica de Porto Alegre. Instituto Biológico La Salle. Canoas.

MALME, G.O. 1931. Die Leguminosen der Regnellsch Reise. Arkiv Botan., 23.A (13): 19-21.

PIO CORREA, M. 1926. Dicionário das plantas úteis no Brasil e das exóticas cultivadas. Imprensa Nacional. Rio de Janeiro. v.1.

POLHILL, R.M. 1981. Indigofereae. In: POLHILL, R.M. \& RAVEN, P.H. eds. Advances in legume systematics. Royal Bot. Gardens. Kew. v.2, pt.1.

RADFORD, A.E. 1974. Phytography - morphological evidence. In: RADFORD, A.E.; DICKISON, W.C.; MASSEY, J.R. \& BELL, R. Vascular plant systematics. Harper \& Row. New York.

RAMBO, B.S.J. 1953. Estudo comparativo das leguminosas riograndenses. An. Bot. Herb. Barb. Ror., 5 (5): 3-80.

RAMBO, B.S.J. 1966. Leguminosae riograndenses. Pesquisas, sér. bot., $23: 1-66$.

RYDBERG, P.A. 1923. Indigofereae e Galegeae. In: NORTH AMERICAN FLORA. v.24, n.3.

SCHULTZ, A.R.H. \& PORTO, M.L. 1971. Nota prévia sobre o levantamento florístico de quatro regiōes naturais do Rio Grande do Sul. Iheringia, sér. bot., (15): 19-47.

SCHULZE-MENZ, G.K. 1964. Leguminosae. In: MELCHIOR, H. ed. Syllabus der pflanzefamilien. 12.ed. Gerbrüder Borntrager. Berlin-Nikolasse. v.2.

STANDLEY, P.C. 1920-26. Trees and shrubs of Mexico. Contrib. Unit. St. Nat. Herb., $23: 438-41$, 476-7.

STANDLEY, P.C. 1930. Flora of Yucatan. Field. Mus. Nat. Hist. Public. bot., ser., 279 (3): 303-4.

TAUBERT, P. 1894. Leguminosae. In: ENGLER, A. \& PRANTL, K. Die naturlichen pflanzefamilien. Wilhelm Engelman. Leipzig. v.3, pt.3. 